\title{
Breast-Feeding is Not a Risk Factor of Mother-to- Child Transmission of Hepatitis B Virus
}

\author{
Mingshu Zhou \\ Li Li \\ Lirong Han \\ Fangli Sun \\ Nuo Yi
}

Department of Obstetrics and Gynecology, Beijing Ditan Hospital Capital Medical University, Beijing, China
Correspondence: Mingshu Zhou; Nuo Yi Department of Obstetrics and Gynecology, Beijing Ditan Hospital, 8 Jingshun East Street, Chaoyang District, Beijing, I000I5, People's Republic of China

Email suniezhou@ccmu.edu.cn;

dr986986@sohu.com
Purpose: This study aims at researching the content of hepatitis B virus (HBV) DNA in the breast milk of the mothers carrying HBV and investigating the effects of different feeding methods on mother-to-child transmission (MTCT) of HBV.

Methods: All infants were voluntarily chosen by their mothers and divided into breastfeeding group and formula-feeding group, which were divided into three subgroups, respectively: HBV-DNA negative (HBV-) group, low viral load (LVL) group and high viral load (HVL) group.

Results: HBV load in colostrum and mature milk were both significantly lower than in serum $(\mathrm{P}<0.001)$. The positive rate of HBV-DNA in colostrum was positively correlated with HBV load in serum, significantly higher than that of the HBV-Group in colostrum in the LVL Group ( $\mathrm{P}<0.05)$, and the HVL Group was significantly higher than the LVL Group (P $<0.001)$. The analysis of risk factors of HBV infection in infants showed that breast-feeding and HBsAg positive in colostrum did not increase the risks of $\mathrm{HBV}$ infection of infants $(\mathrm{P}>$ $0.05)$.

Conclusion: Breast-feeding is safe for infants with HBV-infected mothers who receive active immunization combined with passive immunization. As well, breast-feeding will neither increase the risks of HBV infection for infants nor weaken their immunity to HBV. However, breast-feeding shall be cautiously applied to pregnant women with high viral load. Keywords: hepatitis B virus, mother-to-child transmission, breast-feeding group, formulafeeding Group

\section{Introduction}

As one of the most common communicable diseases, chronic hepatitis B virus (HBV) remains the major cause of liver cirrhosis and hepatocellular carcinoma. ${ }^{1}$ About 200 million people are infected with HBV worldwide, and about 65,000 people die of HBV infection every year. ${ }^{2}$ Acting as the main HBV infection way, approximately 50\% patients are infected through mother-to-child transmission (MTCT), ${ }^{3}$ which may occur during gestation, perinatal, or postpartum. ${ }^{4}$

Most chronic HBV infections occur in China, with estimated 86 million chronic carriers in $2016,{ }^{5}$ and $7.18 \%$ of them were pregnant women. ${ }^{6}$ In China, about one million HBV-infected pregnant women deliver every year, ${ }^{10}$ and most of them have strong desires to breastfeed their infants. However, it is not clear whether breast-feeding increases the risks of HBV transmitted from mothers to infants. For further clarification of this issue, a stratified investigation was performed in this study to evaluate the amount of HBV in the milk and the MTCT rate of HBV based on the feeding methods and the viral load of HBV in serum of HBV-infected 
pregnant women. Since 2015, the positive rate of HBV transmitted from mothers to infants has been reduced to $6 \%{ }^{7}$ after the implementation of active immunization with hepatitis $\mathrm{B}$ vaccine (HBVac) and passive immunization with hepatitis B immunoglobulin (HBIG). For the pregnant women in the third trimester with HBV DNA level in serum $\geq 10^{6}$ copies $/ \mathrm{mL}$, antiviral therapy can improve the blocking rate of MTCT of HBV. ${ }^{8,9}$ Despite these measures, the blocking rate of MTCT of HBV cannot reach $100 \%$.

\section{Materials and Methods}

\section{Selection of the Patients}

The chronic HBV infected pregnant women (aged 25-35) who delivered in Obstetrics and Gynecology Department of Beijing Ditan Hospital Capital Medical University had been followed up from October, 2017 to June, 2019. The inclusive criteria were as follows: 1) voluntary participants; 2) single birth and full-term pregnancy; 3) normal liver function or mild liver dysfunction during gestation, ie, the serum alanine aminotransferase (ALT) level $<3$-fold ULN (upper limit of normal). The exclusive criteria were as below: 1) any antiviral treatments against HBV during gestation; 2) combination with the other viral infections; 3) amniocentesis surgery during gestation; 4) history of placental abruption and prenatal hemorrhage. The study was approved by the Ethics Committee of Beijing Ditan Hospital Affiliated to Capital Medical University. All pregnant women signed a complete informed consent form respectively before their enrollment. This study was conducted in accordance with the Declaration of Helsinki.

All infants were divided into the Breast-feeding Group (in which breast-feeding had lasted for more than 1 month, including exclusive breast-feeding and mixed feeding) and the Formula-feeding Group according to the feeding methods voluntarily chosen by their mothers. According to the serum DNA load of HBV of the pregnant women before delivery, each group was divided into three subgroups: HBV-DNA Negative (HBV-) Group $\left(<5 \times 10^{2}\right.$ copies/ $\mathrm{mL})$, Low Viral Load (LVL) Group $\left(5 \times 10^{2} \sim 1 \times 10^{6}\right.$ copies/mL) and High Viral Load (HVL) Group ( $\geq 1 \times 10^{6}$ copies $/ \mathrm{mL}$ ). Overall, 214 of the total 437 infants were breast-feeding and the other 223 were formula-feeding. In the Breast-feeding Group, 4 cases quitted from followup and there were 79, 68 and 63 patients in HBV-Group, LVL Group and HVL Group, respectively. Meanwhile, with 18 cases quitting from follow-up, in the Formulafeeding Group, there were 73, 53 and 79 patients in HBVGroup, LVL Group and HVL Group, respectively.

\section{Serum Specimens and Detection of DNA and Serologic Markers of HBV}

Respectively, $3 \mathrm{~mL}$ venous blood aseptically collected from pregnant women, $2-4 \mathrm{~mL}$ of colostrum (breast milk at $2-5$ days after parturition) and $2-4 \mathrm{~mL}$ of mature milk collected at one month after delivery was reserved in sterile test tubes for subsequent detection. All newborns were offered a passive immunization intramuscularly with $100 \mathrm{IU}$ HBIG within $2 \mathrm{~h}$ after birth and at 15 to 30 days after birth, respectively. Then, all infants intramuscularly received $10 \mu \mathrm{g}$ of yeast recombinant hepatitis $\mathrm{B}$ vaccine (RHBV) at 1 day, 30 days, and 6 months of age. After completing full-course vaccination, if the infants had no immune response (hepatitis B surface antibody, HBsAb $<$ $10.00 \mathrm{IU} / \mathrm{L})$ or low immune response $(10.00 \mathrm{IU} / \mathrm{L} \leqq$ $\mathrm{HBsAb}<100.00 \mathrm{IU} / \mathrm{L})$, the infants were re-injected with $10 \mu \mathrm{g}$ of RHBV to enhance the immune response.

Chemiluminescent microparticle immunoassay (CMIA) (I2000SR, Abbott, America) was applied to test all serologic markers. The HBV DNA level was quantitatively measured by fluorescent quantitative polymerase chain reaction (FQ-PCR) (LightCycler 480 PCR system, Roche, Switzerland; HBV nucleotide detection kit, fosun medtech, Shanghai, China). The sensitivity of the reagent was $5.0 \times 10^{2}$ copies $/ \mathrm{mL}$, and the linear range of quantitative detection of HBV DNA was 5.0 $\times 10^{2} \sim 9.99 \times 10^{8}$ copies $/ \mathrm{mL}$. The negative criteria of each index were, respectively, as follows: hepatitis B surface antigen (HBsAg) $<0.05 \mathrm{IU} / \mathrm{mL}, \mathrm{HBsAb}<10.00 \mathrm{IU} / \mathrm{L}$ (with the upper limit of detection $1000 \mathrm{IU} / \mathrm{L})$, hepatitis B e antigen (HBeAg) $<1.00$ sample/cut off $(\mathrm{S} / \mathrm{CO})$, hepatitis B core antibody $(\mathrm{HBcAb})<1.00 \mathrm{~S} / \mathrm{CO}, \mathrm{HBV}-\mathrm{DNA}<5 \times 10^{2}$ copies $/ \mathrm{mL}$. And the positive criteria were that HBV-DNA level $\geq 5 \times 10^{2}$ copies $/ \mathrm{mL}$.

\section{Laboratory Methods of Samples of Blood and Breast Milk}

The laboratory methods of blood and milk were carried out as follows: (1) the blood samples had been centrifuged at the speed of $4000 \mathrm{r} / \mathrm{min}$ at room temperature for 5 minutes, and the upper layer of the serum was retained. Similarly, the breast milk had been centrifuged at room temperature at the speed of $4000 \mathrm{r} / \mathrm{min}$ for 5 minutes, and the upper layer of fat was discarded and the whey in the middle layer was retained; (2) $100 \mu \mathrm{L}$ of the samples were taken, and $100 \mu \mathrm{L}$ of extracting solution of nucleic acid was added, and the liquid had been shaken and mixed for $10 \mathrm{~s}$, then it had been centrifuged for 10 minutes; (3) after centrifugation, the supernatant was 
discarded, $50 \mu \mathrm{L}$ of extracting solution of nucleic acid was added, and the liquid had been shaken and mixed for $10 \mathrm{~s}$, and had been kept at $100^{\circ} \mathrm{C}$ for 10 minutes; (4) then, these liquids had been centrifuged at the speed of $1300 \mathrm{r} / \mathrm{min}$ at room temperature for 3 minutes. Later, $7 \mu \mathrm{L}$ of the supernatant was taken and added into the prepared reaction tube, and then it had been centrifuged at a low speed for several seconds, and finally the tube was placed on a quantitative PCR instrument for amplification.

\section{Data Collections}

Details of the pregnant women and the infants in the Breastfeeding Group and the Formula-feeding Group were obtained, including liver function during pregnancy, mode of delivery, gestational weeks at delivery, neonatal birth weight (NBW), $\mathrm{HBeAg}$ levels in venous blood of the newborns at birth, HBVDNA level of the newborns at birth and duration of breastfeeding. The HBV DNA level and serologic markers were detected in peripheral venous blood of the infants at 1 month or 6 months of age to compare the conditions of immune response between the Breast-feeding Group and the Formulafeeding Group. Next, the HBV DNA level and serologic markers were tested to check the status of HBV infection when the infants were at the age of 1-2 years old.

\section{Statistical Analysis}

The data were analyzed with SAS software (Version 9.4). Quantitative data conforming to the normal distribution were expressed as a mean \pm standard deviation (SD), and the independent-sample $t$ test was used for comparing the groups. The quantitative data conforming to skewed distribution were expressed by $\mathrm{M}$ (P25 P75), and the comparison between groups was performed through rank sum test. The counting data were expressed by frequency and rate, and chi-square test or Fisher exact test were used to compare data of the groups. $\mathrm{P}$ value $<0.05$ was considered as being statistically significant.

\section{Results}

\section{Level of HBV-DNA in Milk and Serum}

In the HBV-Group, no HBV-DNA was detected in colostrum and mature milk. In the LVL Group, the positive rate of HBVDNA was $6 \%$ in colostrum, with HBV load at a level of $5 \times 10^{2}-$ $5 \times 10^{4} \mathrm{mmol} / \mathrm{L}$, and no HBV-DNA was detected in mature milk. In the HVL Group, the positive rate of HBV-DNA was $78.6 \%$ in colostrum, $21.4 \%$ of the pregnant women with an HBV load $<5 \times 10^{2} \mathrm{mmol} / \mathrm{L}, 58.2 \%$ at a level of $5 \times 10^{2}-1 \times 10^{4}$ $\mathrm{mmol} / \mathrm{L}$, and $20.4 \%$ at a level of $1 \times 10^{4}-1 \times 10^{5} \mathrm{mmol} / \mathrm{L}$. Meanwhile, in the HVL Group, the positive rate of HBVDNA was $15.4 \%$ in mature milk, $84.6 \%$ of the pregnant women with an HBV load $<5 \times 10^{2} \mathrm{mmol} / \mathrm{L}, 15.4 \%$ at a level of $5 \times 10^{2}-1 \times 10^{4} \mathrm{mmol} / \mathrm{L}$. Above all, the positive rate of HBVDNA in colostrum was positively correlated with HBV load in serum. The positive rate of HBV-DNA in colostrum of the LVL Group was significantly higher than the HBV-Group $(\mathrm{P}<$ 0.05), and the HVL Group was significantly higher than the LVL Group $(\mathrm{P}<0.001)$, as listed in Table 1.

\section{Characteristics of Pregnant Women and Infants Between Groups}

In the HBV-, LVL, and HVL groups, the characteristics was compared between breast-feeding and formula-feeding groups, respectively. As shown in Table 2, in each viral load group, there were no significant differences of liver functions during pregnancy, NBW, positive rate of $\mathrm{HBeAg}$ at birth, negative rate of $\mathrm{HBeAg}$ at birth and duration of breastfeeding between breast-feeding and formula-feeding groups $(\mathrm{P}>0.05)$. Duration of breast-feeding of HBV-, LVL and HVL groups was $8.1 \pm 5.1$ months, $8.5 \pm 4.5$ months, and 7.2 \pm 4.9

Table I Level of HBV-DNA in Milk of Pregnant Women with Different Viral Load in Serum

\begin{tabular}{|c|c|c|c|c|c|c|c|c|c|c|}
\hline \multirow[t]{2}{*}{ Groups } & \multirow[t]{2}{*}{$\mathbf{N}$} & \multirow{2}{*}{$\begin{array}{c}\text { HBV } \\
\text { Seroprevalence } \\
n(\%)\end{array}$} & \multicolumn{4}{|c|}{ Level of HBV-DNA in Colostrum, $n$ (\%) } & \multicolumn{4}{|c|}{ Level of HBV-DNA in Mature Milk, n (\%) } \\
\hline & & & $<5 \times 10^{2}$ & $\begin{array}{c}5 \times 10^{2} \sim \\
1 \times 10^{4}\end{array}$ & $>1 \times 10^{4 \sim 5}$ & Positive & $<5 \times 10^{2}$ & $5 \times 10^{2} \sim 1 \times 10^{4}$ & $>1 \times 10^{4 \sim 5}$ & Positive \\
\hline HBV- & 104 & $0(0.0)$ & $104(100.0)$ & $0(0.0)$ & $0(0.0)$ & $0(0.0)^{\mathrm{a}}$ & $104(100.0)$ & $0(0.0)$ & $0(0.0)$ & $0(0.0)^{\mathrm{d}}$ \\
\hline LVL & 83 & $83(100.0)^{g}$ & $78(94.0)$ & $5(6.0)$ & $0(0.0)$ & $5(6.0)^{b}$ & $67(100.0)$ & $0(0.0)$ & $0(0.0)$ & $0(0.0)^{\mathrm{e}}$ \\
\hline HVL & 98 & $98(100.0)^{\mathrm{h}}$ & $21(21.4)$ & $57(58.2)$ & $20(20.4)$ & $77(78.6)^{\mathrm{c}}$ & $55(84.6)$ & $10(15.4)$ & $0(0.0)$ & $10(15.4)^{f}$ \\
\hline
\end{tabular}

Notes: Comparison between HBV-, LVL and HVL group about the positive rate of HBV-DNA in colostrum: ${ }^{\text {a vs }}{ }^{b} p=0.01$ I; ${ }^{\text {a vs }}{ }^{c} p<0.001$; ${ }^{b}$ vs ${ }^{c} p<0.001$. Comparison between HBV-, LVL and HVL group about the positive rate of HBV-DNA in mature milk: ${ }^{d v s} f_{P}<0.001$; ${ }^{e v s} f_{p}<0.001$. Positive rate of HBV-DNA between serum and colostrum in LVL group: ${ }^{g}$ vs bP < 0.00I; Positive rate of HBV-DNA between serum and colostrum in HVL group: ${ }^{\text {h vs }} \mathrm{c} P<0.00 \mathrm{l}$; Positive rate of HBV-DNA between serum

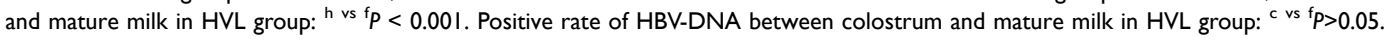

Abbreviations: HBV-, HBV-DNA negative group; LVL, low viral load group; HVL, high viral load group. 


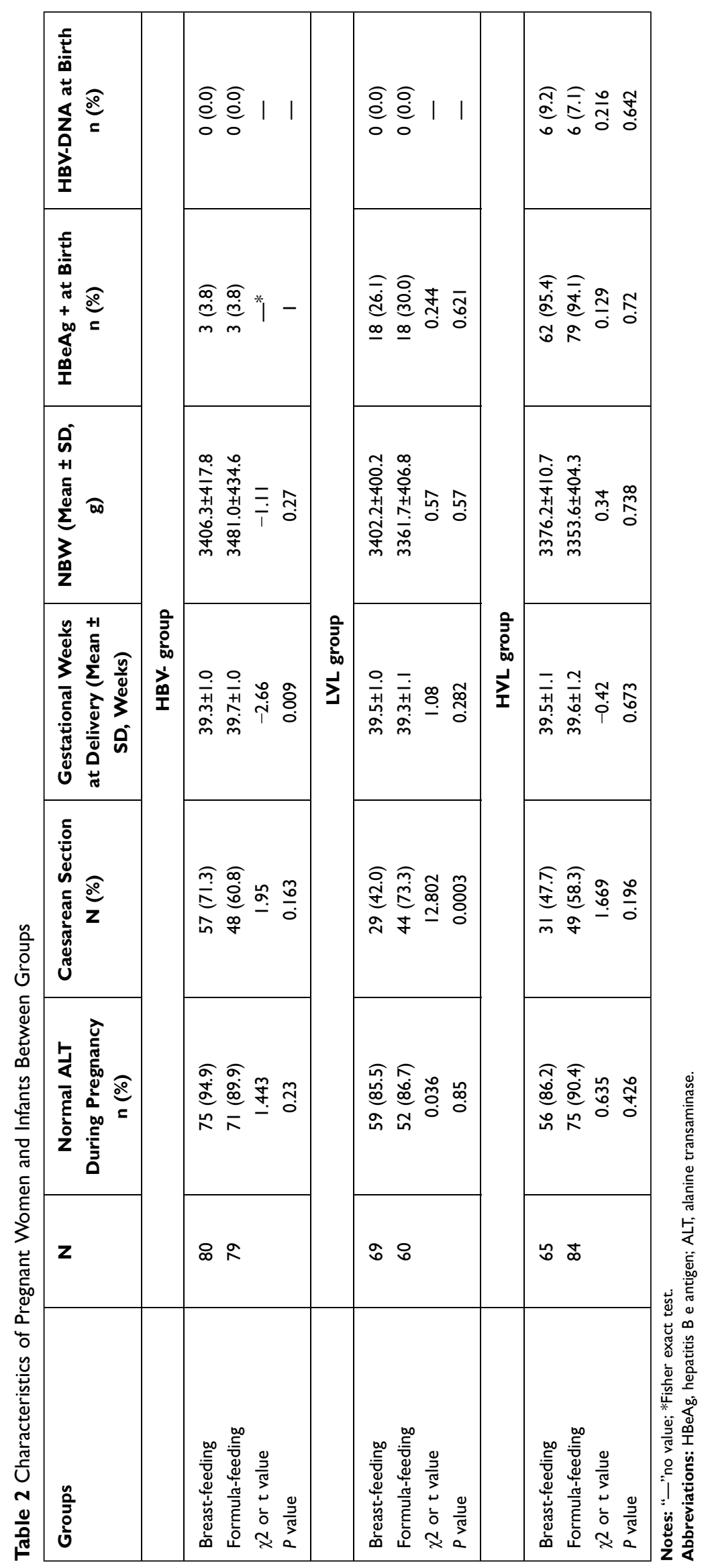


months, respectively, without statistically significant differences $(\mathrm{P}=0.3076)$.

\section{HBV Infection Rate and Immune Response of the Infants}

In this study, all infants had been followed up to 1-2 years old. As shown in Table 3, in the HBV-Group, the HBV infection rate of the breast-feeding infants and formulafeeding infants was $1.8 \%$ and $3.4 \%$, respectively. And there was no statistically significant difference between both groups $(\mathrm{P}>0.05)$. In the LVL Group, there was no infection in the breast-feeding and formula-feeding infants. In the HVL Group, the HBV infection rate of breast-feeding infants and formula-feeding infants was $11.1 \%$ and $2.2 \%$, respectively. The infection rate of the breast-feeding infants indicated herein was higher than that of formula-feeding infants, without significant difference $(\mathrm{P}>0.05)$.

As for the immune response, when the infants were 1 month and 7 months old, the positive rate of HBsAb was shown without any significant difference $(\mathrm{P}>0.05)$ between the breast-feeding and formula-feeding groups, which could be seen in the HBV-, LVL and HVL groups, as shown in Table 3.

\section{Analysis of Risk Factors of HBV Infection in the Infants}

A logistic regression analysis was used for analyzing the risk factors of $\mathrm{HBV}$ infection in the infants. As seen from the results, the breast-feeding method, with positive HBsAg in colostrum and the high HBV-DNA load in serum of pregnant women were all not high-risk factors of HBV infection for the infants $(\mathrm{P}>0.05)$, as listed in Table 4.

\section{Discussion}

The primary factors affecting breast-feeding of the HBVinfected women include an application of antiviral drugs, concerns about MTCT, objections of family, and so on. It remains uncertain that whether the breast milk of HBVinfected women contained hepatitis $\mathrm{B}$ virus and whether breast-feeding could increase the risks of MTCT of HBV. Some studies suggested that the level of HBV-DNA in serum of pregnant women $\geq 1.0 \times 10^{6}$ copies $/ \mathrm{mL}$ could be considered as a high-risk threshold for MTCT of $\mathrm{HBV}^{11}$
Song and $\mathrm{Hou}^{12}$ demonstrated that when the concentrations of HBsAg infection in serum of pregnant women were $>500 \mathrm{ng} / \mathrm{mL}, 300-500 \mathrm{ng} / \mathrm{mL}$, and $<300 \mathrm{ng} / \mathrm{mL}$, the positive rates of HBV-DNA in breast milk were $66.7 \%$, $39.4 \%$, and $15.0 \%$, respectively. Chen's study pointed out that there were statistically significant differences between the level of HBV-DNA in breast milk and serum. And the level of HBV-DNA in breast milk was positively correlated with that in serum. When HBV-DNA and HBeAg were both positive in serum, the positive rate of $\mathrm{HBV}$ DNA in milk can reach $75.71 \%$. And while the HBV-DNA in serum was positive but $\mathrm{HBeAg}$ was negative, the positive rate of HBV-DNA in breast milk was $18 \%{ }^{13}$ Most previous studies only focused on the HBV-DNA load in colostrum. Nevertheless, in our study, the HBV-DNA load in colostrum and mature milk were both studied. As the results displayed, the HBV-DNA was not detected in colostrum and mature milk in the HBV-Group. In the LVL Group, the positive rate of HBV-DNA was just $6 \%$ in colostrum with a lower load of HBV-DNA, and no HBV-DNA was detected in mature milk. In the HVL Group, the positive rate of HBV-DNA was $78.6 \%$ in colostrum, which was significantly higher than that in HBV- and LVL groups, as well with a relatively higher HBV load in breast milk. In the HVL Group, the positive rate of HBV-DNA was $15.4 \%$ in mature milk, which was significantly higher than that in HBV- and LVL groups. Therefore, according to the previous studies, the results of this study showed that the positive rate of $\mathrm{HBV}$ in the breast milk was significantly lower than that in serum. Furthermore, HBV load in milk was positively correlated with the viral load in serum. When the HBV-DNA in serum of pregnant women was $<1 \times 10^{6}$ copies $/ \mathrm{mL}$, the positive rate of $\mathrm{HBV}$ in colostrum was quite low, and HBV cannot be detected in the mature milk. However, when the HBV-DNA in serum was $\geq 1 \times 10^{6}$ copies $/ \mathrm{mL}$, the positive rate of $\mathrm{HBV}$ in colostrum increased significantly. Whereas, the positive rate of HBV in mature milk is lower than in colostrum, and most of the pregnant women with $\mathrm{HBV}$-infection were with lower virus loads in breast milk.

Theoretically, if there was HBV in the breast milk, there would be risks that the virus would be transmitted to the infant through the milk, when the nipples of the mothers were cracked or the mucosa of the digestive tract of the infants were damaged. Hence, many researchers believed that the breast milk of $\mathrm{HBV}$-infected pregnant women was contagious, then we should choose an 


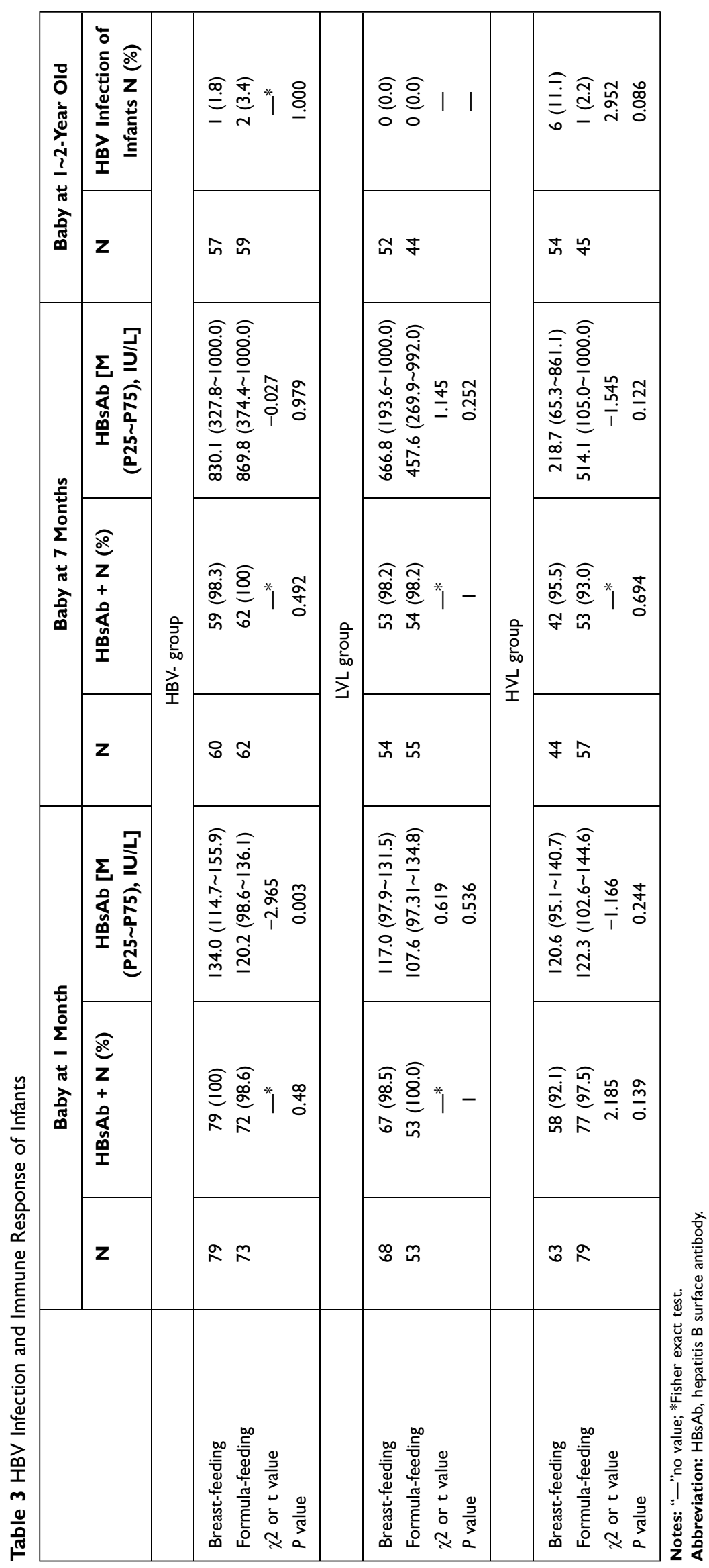


Table 4 Logistic Regression Analysis of Risk Factors of HBV Infection in Infants

\begin{tabular}{|l|c|c|c|}
\hline Variables & Groups & RR (95\% Cl) & P value \\
\hline Method of feeding & $\begin{array}{c}\text { Breast-feeding } \\
\text { Formula-feeding }\end{array}$ & $\begin{array}{c}1.004(0.268,3.763) \\
\text { ref }\end{array}$ & 0.996 \\
\hline HBsAg of colostrum & $\begin{array}{c}\text { Positive } \\
\text { Negative }\end{array}$ & $\begin{array}{c}1.662(0.253,10.90 I) \\
\text { ref }\end{array}$ & 0.597 \\
\hline HBV-DNA load in serum of pregnant women & $\begin{array}{c}\text { Positive } \\
\text { Negative }\end{array}$ & $\begin{array}{c}2.88 I(0.388,21.415) \\
\text { ref }\end{array}$ & 0.301 \\
\hline
\end{tabular}

appropriate method of feeding according to the content of HBV-DNA in serum of pregnant women. When the infants were 6 months old, HBV-DNA was not detected in the peripheral blood of the infants in the Formula-feeding Group, but there were 8 infants (12.9\%) with positive HBV-DNA in the Breast-feeding Group, and the difference was statistically significant $(\mathrm{P}<0.05)$. So, the conclusion of the study was that breast-feeding should be carefully performed in pregnant women with HBV-DNA $\geq 1 \times 10^{6}$ copies/mL before delivery. The other investigators also advocated that the content of HBV in breast milk should be detected before breast-feeding, and then decide whether to breastfeed or not. In addition, it was thought that breastfeeding would not be recommended if the detection of HBV in breast milk was positive. In contrast, the other studies like Huang YT's study ${ }^{14}$ persisted that although the level of HBV-DNA in breast milk increased along with the HBV-DNA level in serum, the positive rate of HBsAg and $\mathrm{HBs} \mathrm{Ab}$ showed no significant difference between the Breast-feeding Group with different titers of HBV-DNA and the Formula-feeding Group.

Would breast-feeding from $\mathrm{HBV}$-infected pregnant women increase the risk of mother-to-child transmission of hepatitis B virus? In order to solve the problem, a study was conducted to investigate the HBV infection rate of the breast-feeding newborns with 24-month follow-up. The results showed that, in each viral load group, no significant differences of liver function during pregnancy, NBW, positive rate of $\mathrm{HBeAg}$ at birth, negative rate of $\mathrm{HBeAg}$ at birth and duration of breast-feeding were found between the breast-feeding and formula-feeding groups. In LVL group, cesarean delivery rate of the Formula-feeding Group was higher than that of the Breast-feeding Group, with significant differences. In this study, all infants had been followed up to 1-2 years old. In the HBV-Group, the $\mathrm{HBV}$ infection rate of the breast-feeding infants and formula-feeding infants was $1.8 \%$ and $3.4 \%$, respectively. And there was no statistically significant difference between both groups. In the LVL Group, there was no infection in the breast-feeding and formula-feeding infants. In the HVL Group, the HBV infection rate of the breast-feeding infants was $11.1 \%$, while that of the formula-feeding infants was $2.2 \%$. The infection rate of the breast-feeding infants was higher than that of the formulafeeding infants, without significant differences.

The results of Wang Zhen's study ${ }^{15}$ suggested that the HBV-infected rates of the infants at 7-12 months old, with low viral load in serum, between the breast-feeding and formula-feeding groups were $1.7 \%$ and $1.6 \%$, respectively, without significant differences. As well, for the infants with high viral load, the HBV-infected rates were 9.5\% and $10.9 \%$, similarly, without significant differences. Different with these studies, our study revealed that in the HVL Group, the rate of $\mathrm{HBV}$ infection of the breast-feeding infants was higher than that of the formula-feeding infants, which might be related to the grouping methods of virus load, duration of breast-feeding and the length of follow-up. Being consistent with the previous studies, the results of our study also showed that there was no significant difference in $\mathrm{HBV}$-infected rates between the breast-feeding and the formula-feeding infants, indicating that breast-feeding did not increase the risks of HBV through MTCT. (In the HBV-negative group, newborns were followed up to 1-2 years, 1 was infected by breastfeeding, and 2 were infected by artificial feeding. At the 6th weeks and 7th months after delivery, hepatitis B surface antigen and HBV-DNA were negative, so close contact infection with other hepatitis B virus carriers was not excluded.)

Newborns could produce antibody against HBV after reception of active and passive immunization, which may resist to the virus in breast milk. Newborns with HBVinfected mothers should be vaccinated with HBIG within 12 hours after birth and receive all-course inoculation (at 0 
month, 1 month, and 6 months). The passive immunoreactivity of HBIG worked within 15 30 min after injection, and the effects had lasted for 42-63 days. The active immunity was produced 35-40 days after inoculation of RHBV, and the level of HBsAb in serum increased significantly after the third vaccination of HBIG. Five makers (HBsAg, HBsAb, HBeAg, HBeAb, and HBcAb) of hepatitis $B$ were detected at 1 month after the whole course of vaccination to evaluate the immune response to $\mathrm{HBV}$, among these, HBsAb $\geq 100 \mathrm{mIU} / \mathrm{mL}$ was defined as an effective response (normal response), $10 \sim 100 \mathrm{mIU} / \mathrm{mL}$ was a low response, $<10 \mathrm{mIU} / \mathrm{mL}$ meant without any response. ${ }^{16}$ After the whole course of immunization, the average titer of HBsAb was the highest in the 7-11 months old infants, representing the peak of immunoreactivity. Newborns in this study were all inoculated with HBIG within 2 hours and at 15-30 days after birth, respectively, and fully vaccinated with the whole course of RHBV. The results suggested that in the HBV-, LVL and HVL groups, no significant difference about the positive rate of $\mathrm{HBs} \mathrm{Ab}$ was observed between breast-feeding and formula-feeding groups when the infants were 1 month and 7 months old. In HBV-Group, the HBsAb titers of the 1-month-old breast-feeding infants were significantly higher than that of the formula-feeding infants, with significant differences. For 7-month-old infants, there was no significant difference of the HBsAb titers between both groups. And in the LVL and HVL groups, there was no significant difference of the HBs-Ab titers between breast-feeding and formulafeeding infants at the age of 1 month and 7 months. In all, the results suggested that breast-feeding would not weaken the baby's immune response. The results of our study ${ }^{17}$ were consistent with those of Huang Ruijuan's study. In our study, the analysis of risk factors of HBV infection in infants showed that breast-feeding and HBsAg positive in colostrum did not increase the risk of HBV infection of the infants. Nevertheless, the results of this study showed that high HBV-DNA load in serum of pregnant women was not a high-risk factor for HBV infection of the infants, which were different from the previous results. ${ }^{18,19}$ However, this may be related to the small sample size of the infants with HBV positive in this study. In addition, because the detection method in our hospital was limited during the study period, real-time PCR was not adopted, and in the relevant studies in the future, we will use the detection method with higher sensitivity.

\section{Conclusions}

In summary, the results of our study showed that breastfeeding was safe for the infants with HBV-infected mothers who received active immunization on combination with passive immunization. Under this circumstance, breast-feeding would not increase the risk of HBV infection for the infants and would not reduce their immunity to $\mathrm{HBV}$. However, it is recommended to give an individualized guidance to the mothers with different viral loads in serum respectively. When the nipples of the mothers are cracked or the infants have oral ulcers, it is safer to stop breast-feeding, especially for the mothers with high viral loads. As with a small sample size of our study, further studies with large sample sizes are needed.

\section{Disclosure}

The authors report no conflicts of interest in this work.

\section{References}

1. Frank W, Rohit P, Julie VS, et al. Hepatitis B in pregnancy: a concise review of neonatal vertical transmission and antiviral prophylaxis. Ann Hepatol. 2014;2:187-196.

2. Tan ZM, Yin YZ, Zhou J, et al. Telbivudine treatment of hepatitis B virus-infected pregnant women at different gestational stages for the prevention of mother-to-child transmission: outcomes of telbivudine treatment during pregnancy. Medicine (Baltimore). 2016;95(40):1-8. doi:10.1097/MD.0000000000004847

3. Song YM, Sung J, Yang S, Choe YH, Chang YS, Park WS. Factors associated with immunoprophylaxis failure against vertical transmission of hepatitis B virus. Eur J Pediatr. 2007;166(8):813-818. doi:10.1007/s00431-006-0327-5

4. Ma L, Alla NR, Li XM, et al. Mother-to-child transmission of HBV: review of current clinical management and prevention strategies. Rev Med Virol. 2014;24(6):396-406. doi:10.1002/rmv.1801

5. Stanaway JD, Flaxman AD, Naghavi M, et al. The global burden of viral hepatitis from 1990 to 2013: findings from the Global Burden of Disease Study 2013. Lancet. 2016;388(10049):1081-1088. doi:10.1016/S0140-6736(16)30579-7

6. Sun WH, Zhao SF, Zhao B, et al. Strategies to prevent mother to-child transmission of hepatitis B. World Chin J Digestol. 2016.

7. Chinese Medical Association Society of Infectious Diseases, Chinese Grade Center. Chinese practice guideline for the prevention and treatment of hepatitis B virus mother-to-child transmission. Chinese Journal of Clinical Infectious Diseases. 2019;37(7):388-396.

8. Pan CQ, Duan Z, Dai E, et al. Tenofovir to prevent hepatitis B transmission in mothers with high viral load. $N$ Engl $J$ Med. 2016;374(24):2324-2334. doi:10.1056/NEJMoa1508660

9. Zhang W, Chi PP, Wang FZ, et al. Association of maternal antiviral drugs in addition to standard care for prevention of vertical transmission of hepatitis B virus to infants born to mothers with high hepatitis B virus loads. Chin J Vaccines Immun. 2020;3:14.

10. Cui F, Woodring J, Chan P, et al. Considerations of antiviral treatment to interrupt mother-to-child transmission of hepatitis B virus in China. Int J Epidemiol. 2018;47(5):1529-1537. doi:10.1093/ije/ dyy077

11. Tram T. Management of hepatitis B in pregnancy: weighing the options. Clin J Med. 2009;76(Suppl 3):S25-S29. 
12. Song L, Hou YP. Analysis of the correlation between the content of HBV-DNA in breast milk and the concentration of HBsAg in serum of 110 pregnant women. Exp Lab Med. 2015;6:771-773. [in Chinese].

13. Chen DX. Analysis of the correlation between the level of HBV-DNA in milk and HBV-DNA in serum of 120 hepatitis B virus carriers. J Aerosp Med. 2015;26(11):1368-1369. [in Chinese].

14. Huang YT, Mao ZY. Study on the safety of breast-feeding in pregnant women with positive HBV-DNA in serum. J Qiqihar Univ Med. 2014;35(14):2096-2097. [in Chinese].

15. Wang Z, Han H. Clinical study on different feeding modes of HBsAg-positive women and mother-to-child transmission. Guide China Med. 2019;17(12):158-159. [in Chinese].
16. $\mathrm{Li} \mathrm{L}$. Interpretation of clinical guidelines for the prevention of mother-to-child transmission of hepatitis B virus (1st edition). Chin J Obstet Gynecol Pediatr (Electron Ed). 2014;10(2):136-140. [in Chinese].

17. Rui-Juan H, Kai-Xian H, Su-Qing Z. Safety of breast-feeding by hepatitis B-positive mothers. Chin Gen Pract. 2011;14:3349-3351.

18. Pan CQ, Duan ZP, Bhamidimarri KR, et al. An algorithm for risk assessment and intervention of mother to child transmission of hepatitis B virus. Clin Gastroenterol Hepatol. 2012;10(5):452-459. doi:10.1016/j.cgh.2011.10.041

19. Park JS, Pan CQ. Viral factors for HBV mother-to-child transmission. Hepatol Int. 2017;11(6):476-480. doi:10.1007/s12072-017-9825-y

\section{Publish your work in this journal}

The International Journal of General Medicine is an international, peer-reviewed open-access journal that focuses on general and internal medicine, pathogenesis, epidemiology, diagnosis, monitoring and treatment protocols. The journal is characterized by the rapid reporting of reviews, original research and clinical studies across all disease areas. The manuscript management system is completely online and includes a very quick and fair peer-review system, which is all easy to use. Visit http://www.dovepress.com/ testimonials.php to read real quotes from published authors. 